\title{
PENSAR A MELANCOLIA: DOS HUMORES DE HIPÓCRATES AO PESSIMISMO REVOLUCIONÁRIO DE WALTER BENJAMIN
}

\author{
Marcos Lentino Messerschmidt ${ }^{1}$ \\ Pontifícia Universidade Católica do Rio Grande do Sul (PUCRS) \\ https://orcid.org/0000-0003-1940-3937 \\ E-mail: marcoslmesser@gmail.com
}

\section{RESUMO:}

O presente artigo tem como objetivo apresentar o aspecto revolucionário do pessimismo e da melancolia de Walter Benjamin. Para tanto, realizamos um resgate histórico do conceito de melancolia, desde a teoria hipocrática dos humores, passando pelo "Problema XXX" de Aristóteles, até "Luto e Melancolia", de Freud. Em seguida, realizamos uma exposição de um excerto da obra "Origem do drama trágico alemão", onde Walter Benjamin apresenta uma breve análise da noção de melancolia no período Barroco, sobre o qual seu texto se detém. Finalmente, analisamos o ensaio "O surrealismo: o último instantâneo da inteligência europeia", de autoria de Walter Benjamin, onde cremos estar presente a gênese dos elementos que virão a ser a base do entendimento do autor sobre a melancolia, fundamentalmente a ideia de uma necessária organização do pessimismo, visando à revolução. Ao distanciar-se das noções sobre o sentimento melancólico previamente concebidas, Walter Benjamin inaugura uma nova visão sobre a melancolia, não mais apática, mas ativa e revolucionária.

PALAVRAS-CHAVE: Walter Benjamin; Melancolia; Pessimismo; Revolução.

\section{TO THINK THE MELANCHOLY: FROM HIPPOCRATES TO WALTER BENJAMIN'S REVOLUTIONARY PESSIMISM}

\begin{abstract}
:
This article aims to present the revolutionary aspect of Walter Benjamin's pessimism and melancholy. To this end, we have made a historical rescue of the concept of melancholy, from the Hippocrates' theory of humors, through "Problem XXX" by Aristotle, to "Mourning and Melancholia" by Freud. Next, we present an excerpt from the work "Origin of the German Tragic Drama", where Walter Benjamin presents a brief analysis of the notion of melancholy in the Baroque period, on which his text dwells. Finally, we analyze the essay "Surrealism: the last snapshot of European Intelligentsia", written by Walter Benjamin, where we believe the genesis of the elements that will become the basis of the author's understanding of melancholy is present, fundamentally the idea of a necessary organization of pessimism, aiming at revolution. By distancing himself from the notions about melancholic feeling previously conceived, Walter Benjamin inaugurates a new vision about melancholia, no longer apathetic, but active and revolutionary.
\end{abstract}

KEYWORDS: Walter Benjamin; Melancholy; Pessimismo; Revolution.

\footnotetext{
${ }^{1}$ Doutorando em Filosofia na Pontifícia Universidade Católica do Rio Grande do Sul (PUCRS), Porto Alegre - RS, Brasil.
} 


\section{Considerações iniciais}

A busca pela compreensão do sentimento melancólico atravessa os milênios. Desde a antiguidade, muitos esforços têm sido dedicados a essa investigação ainda perene na filosofia e psicologia contemporâneas, entre outros campos do conhecimento. O termo "melancolia" persiste, embora as diferentes interpretações sobre o tema ao longo destes milhares de anos sejam incontáveis. Procuraremos traçar aqui uma breve linha evolutiva do entendimento acerca da chamada "bile negra", desde a teoria hipocrática dos humores, passando pelo Problema $X X X$, atribuído a Aristóteles, até chegar a Luto e Melancolia, de Freud. Ato contínuo, dirigiremos nossa atenção a um pequeno, embora fundamental, excerto de Origem do drama barroco alemão, em que Walter Benjamin, ao realizar um extenso resgate histórico do tema, acaba por elaborar uma primorosa síntese de como era entendida a melancolia no Barroco, período sobre o qual o autor se detém no texto referido.

$O$ interesse de Walter Benjamin pela melancolia, para além de Origem do drama barroco alemão, permeia sua obra como um todo, sendo tema recorrente em muitos de seus escritos subsequentes, especialmente aqueles redigidos nos últimos anos antes de seu suicídio. O pessimismo, a experiência da perda e a melancolia são objeto de sua análise em, por exemplo, Experiência e pobreza (1933), O narrador (1936), Sobre alguns motivos na obra de Baudelaire (1939) e nas celebradas teses Sobre o conceito de história (1940). No entanto, a fim de entendermos em que consiste o caráter revolucionário de sua melancolia, retornaremos ao ensaio $O$ surrealismo: o último instantâneo da inteligência europeia, publicado na revista Literarische Welt em 1929.

Por fim, amparados por comentários dos pensadores marxistas brasileiros Michael Löwy e Leandro Konder, examinaremos brevemente como, e em que medida, a melancolia e o pessimismo benjaminianos estão relacionados às noções de melancolia previamente desenvolvidas.

\section{A teoria dos quatro humores}

Na primeira parte de $A$ tinta da melancolia: Uma história cultural da tristeza, o psiquiatra, crítico literário e historiador suíço Jean Starobinski resgata uma clássica acepção da melancolia, constante no aforismo 23 da seção VI dos aforismos de Hipócrates (460 - 377 a.C.): "Si metus et tristitia multo tempore perseverant, melancholicum hoc ipsum" ${ }^{2}$. Quando em excesso, a chamada "bile negra", considerada um dos quatro humores corporais além do sangue, da bile amarela e da pituíta, seria o elemento causador da condição apontada por Hipócrates. Tal condição acarretaria, para além dos sintomas psicológicos persistentes descritos em seu aforismo, também alguns outros, como "epilepsia, loucura furiosa (mania), tristeza, lesões cutâneas etc" (STAROBINSKI, 2016, p. 20). Segundo Starobinski, "O estado que hoje chamamos de melancolia não é mais que múltiplas expressões do poder patogênico da bile negra, quando o seu excesso ou a sua alteração qualitativa comprometem a isonomia (isto é, o equilíbrio harmonioso) dos humores" (STAROBINSKI, 2016, p. 20). Entendemos ser esta a concepção que virá a coincidir com a visão sobre a melancolia desde Aristóteles até Benjamin, conforme buscaremos demonstrar a seguir.

O caráter ambivalente que o termo melancolia traz consigo desde sua gênese será fundamental para a formação de tal ponto de vista, conforme declara Starobinski:

Aqui intervém uma ambiguidade. A palavra "melancolia" designa um humor natural, que não pode ser patogênico. E a mesma palavra designa a doença mental produzida pelo excesso ou pela desnaturação desse humor quando ele se interessa principalmente

\footnotetext{
2 "Se o medo e a tristeza perseveram por muito tempo, isto indica melancolia." (HIPÓCRATES. Aforismos de Hipócrates en latín y castellano. Trad. García Suelto. 7. ed. Barcelona: Editorial Pubul, 1923. Tradução nossa.)
} 
pela "inteligência". Porém, essa desordem não se dá sem algum privilégio: ela confere a superioridade de espírito, acompanha as vocações heroicas, o gênio poético ou filosófico. Essa afirmação, que encontramos nos Problemata aristotélicos, exercerá uma influência considerável na cultura do Ocidente. (STAROBINSKI, 2016, p. 22)

\section{O homem de gênio e a melancolia}

Não há estudo sobre a ideia de melancolia que possa prescindir da leitura do Problema $X X X$. O fragmento, atribuído a Aristóteles (384 - 322 a.C.), trata da relação entre o homem de gênio e a melancolia. Na abertura do texto, o autor sentencia: todos os homens de exceção "resultan ser claramente melancólicos, y algunos hasta el punto de hallarse atrapados por las enfermedades provocadas por la bilis negra" (ARISTÓTELES, 1996, p. 79). Como demonstração de tal tese, são apresentados exemplos de homens de gênio que, segundo o autor, teriam sido acometidos pela afecção melancólica em sua época, como Empédocles, Platão e Sócrates, fazendo-se necessário, escreve Aristóteles, "añadir también a la mayoria de los que se han ocupado de poesía” (ARISTÓTELES, 1996, p. 81).

Os pressupostos teóricos do texto acompanham os de Hipócrates, e também os de seus contemporâneos, acerca da bile negra. Este humor poderia tornar-se quente ou frio conforme as circunstâncias, influenciando aquele que fosse afetado por estas variações, fazendo com que seu temperamento pudesse transformar-se, indo de um extremo a outro. A bile negra, quando fria, tornaria o sujeito torpe e medroso; quando excessivamente quente, o tornaria maníaco e temerário. Aristóteles estatui, então, em que ponto a melancolia torna-se característica do homem de gênio: quando nem tão quente e nem tão fria, em um estado médio, a bile negra torna os sujeitos "melancólicos, pero más inteligentes, y menos excéntricos, al tiempo que en muchos aspectos se muestran superiores a los demás, unos en lo que respecta a la cultura, otros en lo concerniente a las artes, y otros, en fin, en el gobierno de la ciudad" (ARISTÓTELES, 1996, p. 93)

Por fim, Aristóteles evidencia o que parece ser o seu objetivo primeiro, pois o Problema $X X X$ não aborda a "bile negra" apenas como algo que traz como consequência uma enfermidade, mas, sim, como o traço que distingue o homem de gênio de seus semelhantes, já que "todos los melancólicos son seres excepcionales, y no por enfermedad, sino por naturaleza" (ARISTÓTELES, 1996, p. 103).

\section{Freud e a melancolia}

A exemplo do que se passou com aqueles que o antecederam na busca pelo entendimento da afecção melancólica, Sigmund Freud deparou-se com a multiplicidade de sentidos que a chamada "melancolia" foi adquirindo ao longo dos séculos. Em Luto e Melancolia, publicado em 1917, ao realizar uma comparação do afeto envolvido no luto com aquele respectivo à melancolia, Freud busca esclarecer a natureza desta que, segundo suas palavras, "apresenta-se em formas clínicas tão diversas que ainda não é possível resumi-las num conjunto único". A escolha por esta analogia se dá "tanto pelas semelhanças do quadro geral dessas duas condições, como pelo fato de as circunstâncias da vida que as desencadeiam coincidirem" (FREUD, 2006, p. 103).

O luto, considerado condição superável, não é classificado como um estado patológico, sendo

[...] em geral, a reação à perda de uma pessoa amada, ou à perda de abstrações colocadas em seu lugar, tais como a pátria, liberdade, um ideal, etc. Entretanto, em algumas pessoas - que por isso suspeitamos portadoras de uma disposição patológica sob as mesmas circunstâncias de perda, surge a melancolia, em vez do luto. (FREUD, 2006, p. 103) 
Por tratar-se do resultado de uma disposição patológica, e guardadas as devidas proporções, cremos poder relacionar o que Freud chama de melancolia ao que hoje se entende como depressão ${ }^{3}$, já que para ele a melancolia

[...] caracteriza-se psiquicamente por um estado de ânimo profundamente doloroso, por uma suspensão do interesse pelo mundo externo, pela perda de capacidade de amar, pela inibição geral das capacidades de realizar tarefas e pela depreciação do Sentimento-de-Si. (FREUD, 2006, p. 103-04)

Luto e melancolia compartilham causas e sintomas análogos: a perda de algo e a tristeza decorrente desta perda. Em ambos podemos encontrar "a mesma perda da capacidade de escolher qualquer novo objeto de amor" (FREUD, 2006, p. 104), podendo a melancolia também ser "uma reação à perda de um objeto amado" (FREUD, 2006, p. 105). Entretanto, destaca-se uma diferença fundamental entre os dois sentimentos: enquanto no processo de luto o objeto perdido é determinado (como na ocasião do falecimento de uma pessoa próxima ao enlutado, por exemplo), o sentimento do melancólico se dirige à perda de "um objeto que escapa à consciência, diferentemente do processo de luto, no qual tal perda não é nada inconsciente" (FREUD, 2006, p. 105). O processo de luto tem prazo determinado, pois, após este se encontrar terminado, "o Eu se torna efetivamente livre e volta a funcionar sem inibições" (FREUD, 2006, p. 105). O Eu melancólico, no entanto, por não ter seu objeto claramente definido, não goza deste mesmo privilégio: “a inibição melancólica nos parece enigmática, porque não podemos ver o que estaria absorvendo de tal maneira o doente" (FREUD, 2006, p. 105).

A depreciação do Sentimento-de-Si acarretada pelo processo melancólico leva aquele que por ela é acometido a fazer autoacusações das mais diversas, sobre as quais Freud declara:

Com relação a algumas outras auto-acusações, notamos que, embora o doente também pareça ter razão, ele apreende a realidade [Wahrheit] de modo mais intenso e agudo do que os não-melancólicos. (FREUD, 2006, p. 106)

Embora redigido séculos após o Problema $X X X$, o texto freudiano repercute a diferença na percepção da realidade que Aristóteles observava entre melancólicos e não-melancólicos. No entanto, enquanto Freud associa essa excepcionalidade apenas a uma enfermidade, Aristóteles, conforme expusemos previamente, a associa à própria natureza do sujeito melancólico.

Tal multiplicidade de interpretações deve-se à polissemia que a palavra melancolia adquiriu ao longo do tempo. No entanto, tais diferenças não redundam, necessariamente, em contradições inexpugnáveis, tendo, pelo contrário, uma função mais agregadora do que desagregadora. As análises de Freud, e aquelas dos que o sucederam, diferenciam-se, em grande medida, da doutrina dos antigos sobre a melancolia, mas dela seguem devedoras, fato brilhantemente descrito por Starobinski:

\footnotetext{
3 Para uma melhor compreensão da relação entre melancolia e depressão, conforme essa é entendida pela psicanálise contemporânea, deixamos como sugestão a leitura da obra $O$ tempo e o cão: a atualidade das depressões, em que a psicanalista Maria Rita Kehl, ao relatar suas leituras acerca deste tema e as discussões que testemunha no meio psicanalítico a respeito do mesmo, propõe um debate mais atualizado, afirmando que, por exemplo, "não é incomum encontrar certa confusão entre as características dos quadros depressivos e melancólicos, que chegam a ser abordados indiscriminadamente, como se fossem a mesma coisa. Não são. As características 'depressivas' do melancólico - negativismo, falta de ânimo, falta de auto-estima, distúrbios somáticos e outras tantas manifestações de dor psíquica - podem se parecer, empiricamente, com a dos depressivos. Mas assim como algumas crises histéricas e algumas construções do pensamento delirante entre os obsessivos não podem ser confundidas com sintomas psicóticos, a semelhança fenomenológica entre a tristeza e o abatimento dos melancólicos e dos depressivos não são manifestações da mesma estrutura psíquica. (KEHL, Maria Rita. O tempo e o cão. São Paulo: Boitempo Editorial, 2009. p. 39-40.)
} 
A psicologia mudou de linguagem. Não mais se atém à antiga doutrina humoral, da qual a palavra "melancolia" é uma sobrevivência. Está atenta a sintomas mais bem repertoriados, escuta as opiniões de uma bioquímica mais fina, de uma melhor ciência da hereditariedade. Mas nem por isso desistiu de formular conjecturas sobre a psicogênese da melancolia, nem de lhe dedicar uma atenção tão rigorosa quanto possível. Ora, tanto nas suas hipóteses etiológicas como em suas listas de sintomas, os psicólogos contemporâneos não parecem ter rompido com a tradição literária e erudita que acaba de ser evocada. (STAROBINSKI, 2016, p. 141)

\section{Uma arqueologia da melancolia no livro sobre o Trauerspiel}

A obra Origem do drama trágico alemão 4 marca o fim prematuro da carreira acadêmica de Walter Benjamin. Alguns anos após a defesa de sua tese, intitulada $O$ conceito de crítica de arte no romantismo alemão, com a qual doutorou-se na Universidade de Berna, Benjamin apresenta o trabalho sobre o drama barroco ${ }^{5}$ como tese de habilitação para concorrer a uma vaga de livredocente na Universidade de Frankfurt. No entanto, como relata Sergio Paulo Rouanet na apresentação da primeira publicação do livro sobre o Trauerspiel no Brasil, suas expectativas quanto ao ingresso na Universidade foram frustradas:

Submetida inicialmente ao Departamento de Literatura alemã, a tese foi recusada, e encaminhada ao Departamento de Estética. Os dois professores que examinaram o texto, por sua vez, rejeitaram o trabalho, e Benjamin foi aconselhado a retirar a tese. Assim terminou, antes de começar, a carreira universitária de Walter Benjamin. (BENJAMIN, 1984, p. 11)

Contudo, o insucesso na primeira recepção deste trabalho de difícil compreensão jamais o impediu de chegar ao lugar que ocupa hoje diante dos interessados no estudo da obra de Walter Benjamin. A leitura do livro sobre o Trauerspiel é imprescindível para qualquer um que queira vir a ter uma visão mais integral do pensamento do autor. Embora seja um texto dedicado ao estudo de uma forma particular da dramaturgia alemã do século XVII, já está ali presente muito do que virá a embasar a totalidade de sua filosofia, principalmente no que se refere à visão de Benjamin sobre uma história dos vencidos, conforme atesta Jeanne Marie Gagnebin:

Este tema da criação sofredora e da natureza decaída prenuncia, já no livro sobre o barroco, a ideia cara de Benjamin dos anos 30 de uma história dos excluídos, dos esquecidos e dos vencidos, que a crítica filosófico-histórica deve extrair por debaixo da camada terrosa da história oficial. (GAGNEBIN, 2013, p. 43)

Faz-se necessário avisar sobre a inevitabilidade de que repitamos aqui alguns dos pontos já abordados nos itens anteriores, sendo tal reincidência indispensável para que possamos notar as escolhas de Benjamin ao elaborar o seu próprio resgate da ideia de melancolia, que, no livro sobre o Trauerspiel, será buscada por ele no momento imediatamente anterior ao Barroco (período em que está centrada a discussão fundamental do texto), o Renascimento.

Interessa a nós, a partir deste momento, a terceira parte do segundo capítulo da obra, intitulada Drama trágico e tragédia, onde Benjamin, ao procurar aprofundar o entendimento da importância fulcral do sentimento lutuoso nas peças barrocas que se propõe a investigar, e a partir de momentos históricos determinados, acaba por construir o que podemos chamar de uma

4 Também referido frequentemente pelos especialistas como o livro ou a obra "sobre o Trauerspiel".

5 Existem duas traduções disponíveis do Ursprung des deutschen Trauerspiels no Brasil. A primeira, traduzida por Sergio Paulo Rouanet e publicada sob o título Origem do drama barroco alemão; e uma segunda, traduzida por João Barrento, que é a utilizada no presente trabalho, publicada sob o título Origem do drama trágico alemão. 
arqueologia $^{6}$ da melancolia. Desde a antiga doutrina dos humores, passando pela Astrologia medieval e pelo Renascimento, Benjamin constrói um rigoroso tratado sobre a disposição melancólica e seus sintomas, sobre o sujeito melancólico e suas idiossincrasias.

O sentimento predominante no drama barroco, por conta das raízes luteranas de seus autores, é o luto, um "estado de alma em que o sentimento reanima o mundo vazio opondo-lhe uma máscara, para experimentar um prazer enigmático à vista dele". (BENJAMIN, 2016, p. 144). A separação radical entre vida e fé endossada pela religião luterana era o fator responsável por tornar este mundo vazio, pois "aqueles que meditavam e iam mais fundo viam-se na existência como num campo de ruínas preenchido por ações não concluídas e inautênticas" (BENJAMIN, 2016, p. 144), levando a própria vida a se rebelar contra este estado de coisas. A teoria do luto surge, segundo Benjamin, "tal como ela ia se delineando enquanto contraponto para a da tragédia", só podendo "ser desenvolvida através da descrição daquele mundo que se abre diante do olhar do melancólico" (BENJAMIN, 2016, p. 144-45). É a partir deste ponto da obra, ao fundamentar sua análise sobre o luto, que Walter Benjamin começará a construir o que aqui decidimos chamar de uma arqueologia da melancolia.

Apresentando-se como devedor da tradição que lhe antecedeu, e já prenunciando a crítica ao cortejo dos poderosos que virá a aparecer em sua futura filosofia da história ${ }^{7}$, Benjamin afirma:

A meditação profunda (Tiefsinn) é sobretudo própria de quem é triste. No caminho para o objeto - melhor: na via interior ao próprio objeto - esta intenção progride tão lenta e solenemente como os cortejos dos poderosos. $O$ interesse veemente pela ostentação nos dramas políticos de pompa e circunstância, que por um lado representa uma evasão do espaço da pacatez devota, resultou, por outro lado, daquela tendência que leva a meditação profunda a sentir-se atraída pelo pensamento grave. Neste, ela reconhece o ritmo que lhe é próprio. (BENJAMIN, 2016, p. 145)

Walter Benjamin toma a célebre gravura Melancolia I, de autoria do artista Albrecht Dürer $^{8}$, como uma contundente representação da disposição melancólica. Nela, uma misteriosa figura alada ocupa um cenário repleto de elementos aparentemente dispersos, onde "os instrumentos da vida ativa estão espalhados pelo chão como objeto de um estéril ruminar" (BENJAMIN, 2016, p. 146). Segundo Benjamin, embora associada ao período renascentista, esta obra, datada de 1514,

[...] antecipa em muito o Barroco. $\mathrm{O}$ saber de quem medita e a investigação do erudito fundiram-se nela tão intimamente como nos homens do período barroco. $\mathrm{O}$ renascimento investiga o universo, o Barroco as bibliotecas. Tudo o que pensa ganha forma de livro. (BENJAMIN, 2016, p. 146)

\footnotetext{
6 Tomamos "arqueologia" aqui no sentido proposto por Georges Didi-Huberman em seu ensaio A imagem queima: "[...] muito frequentemente, encontramo-nos diante de um imenso e rizomático arquivo de imagens heterogêneas que continua sendo difícil de dominar, organizar e compreender, precisamente porque seu labirinto é feito de intervalos e de lacunas tanto como de coisas observáveis. Tentar uma arqueologia equivale sempre a correr o risco de pôr, umas ao lado das outras, partes de coisas sobreviventes, necessariamente heterogêneas e anacrônicas, visto que procedem de lugares separados e de tempos desunidos pelas lacunas. Contudo, chamamos tal risco de imaginação e montagem." (DIDI-HUBERMAN, Georges. Tradução Helano Ribeiro. Curitiba: Editora Medusa, 2018, p. 36-37.)

7 Conforme colocação de Jeanne Marie Gagnebin que destacamos logo acima.

8 A título de ilustração a respeito do encontro determinante que Walter Benjamin teve com esta obra, gostaríamos aqui de mencionar o que nos é relatado por Márcio Seligmann-Silva: "Em 1913, ele [Benjamin] fez algumas viagens importantes, como sua primeira ida a Paris (cidade na qual depois passou boa parte de seus anos de exílio) e a Colmar. Nesta cidade ele foi visitar o famoso quadro de Mathias Grünewald, o Altar de Isenheim. Na Basílica, ele pôde ver as gravuras de Dürer, O cavaleiro, a morte e o diabo e Melancolia I." (SELIGMANN-SILVA, Márcio. A atualidade de Walter Benjamin e Theodor W. Adorno. 2. ed. Rio de Janeiro: Civilização Brasileira, 2010. p. 21). Note-se que a tese sobre o Trauerspiel foi apresentada em 1925, ou seja, mais de doze anos depois!
} 
O homem do período barroco, que lia o mundo através do livro, vivia em um tempo e em um lugar em que "o livro era considerado um monumento duradouro no contexto da cena natural, rica em manifestações escriturais" (BENJAMIN, 2016, p. 146). No entanto, a mesma disposição que levava o sujeito barroco a afastar-se do mundo para contemplá-lo, poderia levá-lo sem dificuldade "à queda num abismo sem fundo" (BENJAMIN, 2016, p. 147), o abismo da melancolia.

O estudo da disposição melancólica, relembra-nos Benjamin, remonta à Antiguidade, tendo sido o seu complexo de sintomas posteriormente codificado na alta Idade Média, mantendo-se vigente até o Renascimento, para, finalmente, ser herdada pelo Barroco:

\begin{abstract}
As causas destes sintomas eram atribuídas pela patologia dos humores ao excesso do elemento seco e frio no indivíduo. Esse elemento era a bílis negra - billis innaturalis ou atra, por contraste com a bilis naturalis ou candida -, do mesmo modo que se remetia o temperamento úmido e quente (sanguíneo) para o sangue, o úmido e frio (fleumático) para a água e o seco e quente (colérico) para a bílis amarela. Segundo esta teoria, o pâncreas tinha uma importância decisiva para a formação da funesta bílis negra. $O$ sangue "espesso e seco" que para ela corre e se torna dominante inibe o riso e provoca a hipocondria. (BENJAMIN, 2016, p. 152)
\end{abstract}

A seguir, Benjamin faz menção ao modo como Aristóteles liga a disposição melancólica à genialidade, afirmando que a "doutrina dos sintomas da melancolia, tal como é exposta no capítulo XXX dos Problemata, exerceu a sua influência durante mais de dois milênios" (BENJAMIN, 2016, p. 153). Cabe-nos aqui destacar, também, o resgate que Walter Benjamin faz da ligação da genialidade melancólica com o dom divinatório:

Antiga - derivada do escrito de Aristóteles De divinatione somnium - é também a convicção de que a melancolia estimula a capacidade profética. E este resto não recalcado dos teoremas antigos reaparece, na tradição medieval, nos sonhos proféticos atribuídos precisamente ao melancólico. (BENJAMIN, 2016, p. 153)

A associação entre melancolia e dons divinatórios ou proféticos aparece também em outra doutrina abordada neste capítulo, de onde surgirá a figura do sujeito saturnino: a astrologia medieval, gestada sob a influência árabe e derivada da Antiguidade tardia. Segundo Benjamin, por estar "intimamente ligada à doutrina da influência dos astros" (BENJAMIN, 2016, p. 155), a teoria da melancolia, a partir de algumas interpretações, anuncia "um traço dialético da concepção de Saturno que corresponde de forma surpreendente ao conceito grego de melancolia" (BENJAMIN, 2016, p. 155). Saturno era conhecido, na época, como o planeta mais afastado do sistema solar, sendo o caráter meditativo do espírito melancólico atribuído a este astro. Tal como o melancólico, Saturno carrega uma ambiguidade. Sua órbita mais longa equivale tanto a uma maior distância da terra (e, portanto, da vida cotidiana) quanto a um tempo mais propício à reflexão, posto que

[...] a imagem do melancólico colocava a esse tempo, empenhado em aceder a todo o custo às fontes ocultas do conhecimento da natureza, a questão de saber como seria possível roubar a Saturno as energias espirituais sem cair na loucura. (BENJAMIN, 2016, p. 158)

A influência da doutrina astrológica sobre a melancolia está presente também na Melancolia I de Dürer, a qual podemos considerar a imagem fundamental desta parte do livro sobre o Trauerspiel, segundo destaca Benjamin ao referenciar as observações de Marsilio Ficino sobre a famosa gravura, constantes na obra De vita triplici: 
O quadrado mágico que vemos desenhado num quadro por cima da "Melancolia" de Dürer é o selo planetário de Júpiter, cuja influência se opõe às forças obscuras de Saturno. Ao lado desse quadro está pendurada a balança, uma alusão ao signo astrológico de Júpiter. (BENJAMIN, 2016, p. 158)

Conforme podemos observar, aí está posta novamente a questão do equilíbrio necessário ao sujeito melancólico para que este não caia em um abatimento profundo ou em um estado maníaco, que o levaria à loucura. É este equilíbrio que leva, conforme exposto por Aristóteles no Problema $X X X$, à genialidade ou, segundo as doutrinas apresentadas por Benjamin, que concede ao melancólico os seus dons proféticos e divinatórios.

Também o cão, retratado em primeiro plano na gravura düreriana, é objeto de interesse de Benjamin, já que este animal, segundo os antigos, dividiria alguns traços em comum com o sujeito melancólico. O baço, que dominaria o organismo do cão, se alterado, o faria perder a alegria e tornar-se raivoso:

Deste ponto de vista, o cão simboliza o aspecto sombrio da complexão melancólica. Por outro lado, o faro e a resistência do animal permitiram construir dele a imagem do incansável pesquisador e do pensador meditativo. (BENJAMIN, 2016, p. 159)

Ainda, segundo Benjamin, pelo fato de o cão, aí, ser representado adormecido, reforça-se a sua ambivalência enquanto símbolo, pois "se os maus sonhos vêm do baço, os divinatórios são privilégio do melancólico" (BENJAMIN, 2016, p. 159). Conforme observa Francisco Fianco em Eu é o nome do vazio,

[...] em Melencolia I, o cão dá uma sensação de fome e frio, como que para evidenciar o quão miserável e triste pode ser uma existência, apesar da erudição, e não haveria menos melancolia em seu olhar do que no semblante do gênio que domina a composição. (FIANCO, 2010, p. 36)

Benjamin também dirige sua atenção a um elemento presente na gravura que, segundo ele, teria passado despercebido por alguns dos investigadores que o antecederam na análise desta obra:

A salvação de antigos símbolos da melancolia, fornecida por esta gravura e pela especulação coeva, deixou um deles - a pedra - sem comentário, e também Giehlow e outros investigadores parecem não ter dado por ele. Mas ela tem um lugar assegurado no inventário simbólico. (BENJAMIN, 2016, p. 161)

A pedra, massa inerte, além de poder representar a forma mais terrena, fria e seca, pode conter, segundo Benjamin, "uma alusão ao conceito mais propriamente teológico do melancólico, presente num dos pecados capitais: o da acédia, a indolência do coração" (BENJAMIN, 2016, p. 163), pecado que, na Divina Comédia de Dante, pertence ao círculo infernal em que "reina o frio glacial, o que remete para os dados da patologia dos humores, a natureza fria e seca da Terra" (BENJAMIN, 2016, p. 163). A acédia, mal que afetava fundamentalmente os monges e eremitas", formava, segundo Starobinski, "a essência da 'melancolia religiosa' dos autores do

\footnotetext{
9 "Durante toda a Idade Média, um flagelo pior do que a peste que infesta os castelos, as vilas e os palácios das cidades do mundo, abate-se sobre as moradas da vida espiritual, penetra nas celas e nos claustros dos mosteiros, nas tebaidas dos eremitas, nas abadias trapistas dos enclausurados. Acedia, tristitia, taedium vitae, desídia são os nomes que os Padres da Igreja dão à morte que isso instila na alma; e, mesmo que nos elencos das Summae virtutum et vitiorum [Suma das virtudes e dos vícios], nas miniaturas dos manuscritos e nas representações populares dos sete pecados capitais, a sua desolada efígie apareça em quinto lugar, uma tradição hermenêutica antiga torna-o o mais mortal dos vícios, o único para o qual não há nenhum perdão possível." (AGAMBEN, Giorgio. Estâncias: a palavra e o fantasma na cultura ocidental. Tradução Selvino José Assmann. Belo Horizonte: Editora UFMG, 2007, p. 21.)
} 
Renascimento e do século XVII" (STAROBINSKI, 2016 p. 45) e era, como podemos observar na Melancolia de Dürer, motivo frequente nas representações artísticas do período:

[...] o fato é que, desde a Idade Média, o eremita aparece quase constantemente nas alegorias que representam o "temperamento melancólico" ou, o que dá quase no mesmo, os filhos de Saturno. De um lado, o temperamento melancólico predispõe a uma contemplação e às atividades intelectuais: isso é, antes de mais nada, um privilégio, e não um mal; de outro, o perigo se liga intimamente às influências favoráveis, e o contemplativo é exposto aos malefícios da acedia no sombrio campo da atrabílis, apesar das distinções teológicas entre pecado e doença corporal. (STAROBINSKI, 2016, p. 45)

A acédia é a melancolia que "trai o mundo para servir o saber" (BENJAMIN, 2016, p. 164), aquela da qual, honrando sua vocação revolucionária, o pensamento de Walter Benjamin, fundamentalmente em sua maturidade, mais se afasta.

\section{Organizar o pessimismo}

É no ensaio O surrealismo: o último instantâneo da inteligência europeia que nos deparamos com a imagem que cremos fundamentar a inclinação revolucionária da melancolia de Walter Benjamin, a ideia de uma necessária e imperiosa organização do pessimismo. Tal organização significa, segundo o autor,

[...] simplesmente extirpar a metáfora moral da esfera da política, e descobrir no espaço da ação política o espaço completo da imagem. Mas esse espaço da imagem não pode mais absolutamente ser medido de forma contemplativa. Se a dupla tarefa da inteligência revolucionária é derrubar a hegemonia intelectual da burguesia e estabelecer um contato com as massas proletárias, ela fracassou quase inteiramente na segunda parte dessa tarefa, pois esta não pode mais ser realizada contemplativamente. (BENJAMIN, 2016, p. 34-35)

A organização do pessimismo como ato de recusa à passividade dá a tônica do texto, classificado por Michael Löwy como "difícil, às vezes injusto, frequentemente enigmático, sempre inspirado, cravejado de imagens e alegorias estranhas" (LÖWY, 2002, p. 42). O pessimismo absoluto defendido por Benjamin convida à ampla e irrestrita suspeita:

Desconfiança acerca do destino da humanidade europeia, e principalmente desconfiança, desconfiança e desconfiança com relação a qualquer forma de entendimento mútuo: entre as classes, entre os povos, entre os indivíduos. E confiança ilimitada apenas na I. G. Farben e no aperfeiçoamento pacífico da força aérea. (BENJAMIN, 2012, p. 34)

A disposição enérgica e a renúncia à atitude contemplativa são os elementos que acabam por afastar o pessimismo aqui defendido por Benjamin daquele que afeta o melancólico tomado pela acédia, cuja imagem é aqui retomada:

O homem que lê, que pensa, que espera, o flanêur, pertence, do mesmo modo que o fumador de ópio, o sonhador e o ébrio, à galeria dos iluminados. E são iluminados mais profanos. Para não falar da mais terrível de todas as drogas - nós mesmos - que tomamos quando em solidão. (BENJAMIN, 2012, p. 252) 
Ao melancólico já não basta ser o homem de gênio aristotélico, um visionário ou o mero espectador de um naufrágio ${ }^{10}$. Para Walter Benjamin, o pessimismo organizado deve atender ao chamado da revolução:

No momento, os surrealistas são os únicos que conseguiram compreender as palavras de ordem que o Manifesto [comunista] nos transmite hoje. Cada um deles troca a mera gesticulação pelo mostrador de um despertador, que soa, a cada minuto, durante sessenta segundos. (BENJAMIN, 2012, p. 33)

A imagem do despertador que soa ininterruptamente é, de acordo com Michael Löwy, a sugestão de que

[...] o valor único do surrealismo consiste em sua disposição a considerar cada segundo como a porta estreita pela qual pode entrar a revolução - para parafrasear uma fórmula que Benjamin só escreverá bem mais tarde. Porque é da revolução que se trata desde o começo até o fim desse ensaio, e todas as iluminações profanas só têm sentido em relação a este ponto de convergência último e decisivo. (LÖWY, 2002, p. 53)

Conforme afirmamos anteriormente, o pessimismo de Walter Benjamin rompe, de modo definitivo, com a ideia de uma melancolia que renega o mundo para servir ao saber. Sua concepção de uma melancolia ativa, não mais contemplativa, é o cerne e motor de seu pensamento como um todo e aquilo que marca a diferença de Benjamin em relação aos que lhe antecederam.

Em Walter Benjamin: O Marxismo da Melancolia, o filósofo Leandro Konder apresenta este contraste com precisão:

A melancolia, no espírito de nosso autor, precisava ser de um tipo especial, para excluir o risco do efeito paralisador da acedia e para se combinar com o impulso ativo, transformador, do rebelde radical, do lutador. Precisava ser uma melancolia na qual reaparecia o elemento desaparecido da acepção original do termo: a cólera, a indignação dos justos (sem a dimensão patológica que esse sentimento tinha nos atrabiliários). (KONDER, 1999, p. 119)

\section{Considerações finais}

O pensamento de Walter Benjamin, de acordo com nossa investigação, inaugura um novo ponto de vista sobre o pessimismo e a melancolia. Não obstante, conforme sustentamos anteriormente, ele segue devedor de toda a tradição filosófica que o antecedeu. Na teoria hipocrática dos humores e no Problema $X X X$ de Aristóteles, já estavam gestadas as noções que são descritas e analisadas em Origem do drama trágico alemão. Por sua vez, as análises empreendidas no livro sobre o Trauerspiel são basilares para a construção do modo como Benjamin passará a tratar do tema em sua maturidade.

À ideia radical da organização do pessimismo soma-se o impulso transformador da disposição melancólica de um sujeito que não se quer mais como mero observador. $O$ mundo à época de Benjamin, bem como o mundo de hoje, chama à ação. $\mathrm{O}$ despertador surrealista segue a soar, a cada minuto, durante sessenta segundos.

10 Em A imagem queima, Georges Didi-Huberman dá conta de uma tradição filosófica “[...] que questionou para que serviria um pensador - esse ser, com frequência, frágil ou excessivamente melancólico para a vida ativa, míope ou sensível demais, muito magro ou muito gordo, delicado ou dono de pés chatos demais para se engajar em um exército - o fato de ser o espectador de um naufrágio." (DIDI-HUBERMAN, 2018, p. 60) 


\section{Referências}

AGAMBEN, Giorgio. Estâncias: a palavra e o fantasma na cultura ocidental. Trad. Selvino José Assmann. Belo Horizonte: Editora UFMG, 2007.

ARISTÓTELES. El hombre de genio y la melancolía. Trad. Jackie Pigeaud. Barcelona: Quaderns Crema, 1996.

BENJAMIN, Walter. Magia e técnica, arte e política: ensaios sobre literatura e história da cultura. Trad. Sérgio Paulo Rouanet. São Paulo: Brasiliense, 2012.

BENJAMIN, Walter. Origem do drama barroco alemão. Trad. Sergio Paulo Rouanet. Brasiliense: São Paulo. 1984.

BENJAMIN, Walter. Origem do drama trágico alemão. Trad. João Barrento. Belo Horizonte: Autêntica Editora, 2016.

DIDI-HUBERMAN, Georges. A imagem queima. Trad. Helano Ribeiro. Curitiba: Editora Medusa, 2018.

FIANCO, Francisco. Eu é o nome do vazio: Walter Benjamin e a melancolia no Drama Barroco. Passo Fundo: IMED, 2010.

FREUD, Sigmund. Escritos sobre a psicologia do inconsciente: Volume II: 1915-1920. Trad. Claudia Dornbusch. Rio de Janeiro: Imago, 2006.

GAGNEBIN, Jeanne Marie. História e narração em Walter Benjamin. São Paulo: Perspectiva, 2013.

HIPÓCRATES. Aforismos de Hipócrates en latín y castellano. Trad. García Suelto. Editorial Pubul. Barcelona. 1923.

KEHL, Maria Rita. O tempo e o cão. São Paulo: Boitempo Editorial, 2009.

KONDER, Leandro. Walter Benjamin: o marxismo da melancolia. Rio de Janeiro: Civilização Brasileira, 1999.

LÖWY, Michael. A estrela da manhã: surrealismo e marxismo. Trad. Eliana Aguiar. Rio de Janeiro: Civilização Brasileira, 2002.

SELIGMANN-SILVA, Márcio. A atualidade de Walter Benjamin e Theodor W. Adorno. Rio de Janeiro : Civilização Brasileira, 2010.

STAROBINSKI, Jean. A tinta da melancolia: uma história cultural da tristeza. Trad. Rosa Freire D’Aguiar. São Paulo: Companhia das Letras, 2016.

Autor(a) para correspondência: Lentino Messerschmidt, Av. Ipiranga, 6681 - Prédios 8 e 9 - Partenon, 90619-900, Porto Alegre - RS, Brasil. marcoslmesser@gmail.com 